\title{
Interaction in self-flux of systems $M_{2}^{l} \mathrm{O}-\mathrm{P}_{2} \mathrm{O}_{5}-\mathrm{TiO}_{2}-M^{\prime l} \mathrm{O}$
$\left(M^{\prime}-\mathrm{Rb}, \mathbf{R b} / \mathbf{K}, M^{\prime \prime}-\mathrm{Cu}, \mathrm{Zn}\right)$
}

\author{
N.Yu.Strutynska, M.A.Bondarenko, I.V.Zatovsky, \\ A.A.Babaryk, N.S.Slobodyanyk
}

T.Shevchenko National University of Kyiv, 64/13 Volodymyrska Str., 01601 Kyiv, Ukraine

\section{Received January 12, 2015}

\begin{abstract}
Peculiarities of phase formation in the self-flux of systems $M_{2}^{\prime} \mathrm{O}-\mathrm{P}_{2} \mathrm{O}_{5}-\mathrm{TiO}_{2}-M^{\prime \prime} \mathrm{O}\left(M^{\prime}-\right.$ $\mathrm{Rb}, \mathrm{Rb} / \mathrm{K}, M^{\prime \prime}-\mathrm{Cu}, \mathrm{Zn}$ ) were investigated at different molar ratios $M^{\prime} / \mathrm{P}=0.5-1.3$ and fixed values $\mathrm{Ti} / \mathrm{P}=0.3, \mathrm{Ti} / M^{\prime l}=1.0$ in the temperature range of $1000-650^{\circ} \mathrm{C}$. Influence of the nature of alkali metal on interaction in multicomponent phosphate melts at molar ratios $(\mathrm{Rb}+\mathrm{K}) / \mathrm{P}=1.0, \mathrm{Ti} / \mathrm{P}=0.3, \mathrm{Ti} / \mathrm{M}^{\prime \prime}=1.0$ was found. Thus, the presence of potassium in the melts promotes the formation of langbeinite-related complex phosphates at the investigated ratios of components. The obtained phosphates were investigated by X-ray powder diffraction, infrared spectroscopy and optical microscopy.
\end{abstract}

Keywords: as-flux, langbeinite-like, complex, phosphate, FTIR, spectroscopy.

Исследованы закономерности фазообразования в растворах расплавах системы $M_{2}^{\prime} \mathrm{O}-\mathrm{P}_{2} \mathrm{O}_{5}-\mathrm{TiO}_{2}-M^{\prime \prime} \mathrm{O}\left(M^{\prime}-\mathrm{Rb}, \mathrm{Rb} / \mathrm{K}, M^{\prime \prime}-\mathrm{Cu}, \mathrm{Zn}\right)$ с различными мольными соотношениями $M^{\prime} / \mathrm{P}=0.5-1.3$ и фиксированными $\mathrm{Ti} / \mathrm{P}=0.3, \mathrm{Ti} / M^{\prime \prime}=1.0$ в температурном интервале $1000-650^{\circ} \mathrm{C}$. Установлено влияние природы щелочного металла на взаимодействие во многокомпонентных щелочнофосфатных растворах-расплавах, а именно, в разрезе соотношений компонентов $\left.(\mathrm{Rb}+\mathrm{K}) / \mathrm{P}=1.0, \mathrm{Ti} / \mathrm{P}=0.3, \mathrm{Ti} / \mathrm{M}^{\prime l}=1.0\right)$, присутствие калия в расплавах способствует формированию лангбейнитовых фаз. Синтезированные фосфаты исследованы с использованием методов порошковой рентгенографии, ИК и оптической микроскопии.

Взаємодія у розчин-розплавах систем $M_{2}^{\prime} \mathrm{O}-\mathrm{P}_{2} \mathrm{O}_{5}-\mathrm{TiO}_{2}-M^{\prime \prime} \mathrm{O} \quad\left(M^{\prime}-\mathrm{Rb}, \mathrm{Rb} / \mathrm{K}, M^{\prime \prime}-\mathrm{Cu}, \mathrm{Zn}\right)$. Н.Ю.Струтинська, М.О.Бондаренко, І.В.Затовський, А.А.Бабарик, М.С.Слободяник.

Досліджено закономірності фазоформування у розчин-розплавах системи $M_{2}^{\prime} \mathrm{O}_{2} \mathrm{P}_{2} \mathrm{O}_{5}-$ $\mathrm{TiO}_{2}-M^{\prime l} \mathrm{O}\left(M^{\prime}-\mathrm{Rb}, \mathrm{Rb} / \mathrm{K}, M^{\prime l}-\mathrm{Cu}, \mathrm{Zn}\right)$ за змінних мольних співвідношень $M^{\prime} / \mathrm{P}^{5}=$ $0.5-1.3$ та фіксованих $\mathrm{Ti} / \mathrm{P}=0.3, \mathrm{Ti} / M^{\prime \prime}=1.0$ у температурному інтервалі $1000-650^{\circ} \mathrm{C}$. Встановлено вплив природи лужного металу на взаємодію у багатокомпонентних лужнофосфатних розчин-розплавах, а саме, у розрізі співвідношень компонентів $\left.(\mathrm{Rb}+\mathrm{K}) / \mathrm{P}=1.0, \mathrm{Ti} / \mathrm{P}=0.3, \mathrm{Ti} / M^{\prime \prime}=1.0\right)$, присутність калію у розплавах сприяє формуванню ланбейнітових фаз. Синтезовані фосфати охарактеризовано з використанням методів порошкової рентгенографії, ІЧ спектроскопії та оптичної мікроскопії.

\section{Introduction}

Complex phosphates of alkali and polyvalent metals attract huge attention due to their important properties such as electrical, optical, catalytic and other useful for practical using in various industries [1-3]. In this aspect the complex phosphates with three-dimensional framework $\left[\mathrm{M}_{2}{ }_{2}\left(\mathrm{PO}_{4}\right)_{3}\right]$ $\left(\mathrm{M}^{n}\right.$ - polyvalent metal) NASICON-related or langbeinite-related type [4-9] have perspective of using as superionic conductors 
or as resistant matrix for the storage of radioactive waste, respectively [7-9]. The latter explains the considerable amount of scientific works devoted to synthesis and investigation of such compounds.

It is noteworthy the investigation of influence of the nature of alkali metal in multicomponent phosphate melts on formation of the complex phosphates with designed structure is very important especially for development of materials with special properties.

Herein, the results of investigation of phase formation regularities from self-flux $M_{2}^{\prime} \mathrm{O}-\mathrm{P}_{2} \mathrm{O}_{5}-\mathrm{TiO}_{2}-M^{\prime l} \mathrm{O}\left(M^{\prime}-\mathrm{Rb}, \mathrm{Rb} / \mathrm{K}, M^{\prime \prime}\right.$ - $\mathrm{Cu}, \mathrm{Zn}$ ) (in the temperature range 1000$650^{\circ} \mathrm{C}$ and the molar ratios $M^{\prime} / \mathrm{P}=0.5-1.3$, $\mathrm{Ti} / \mathrm{P}=0.3, \mathrm{Ti} / \mathrm{M}^{\prime \prime}=1.0$ ) are presented. The influence of the nature of alkali metals on the crystal formation in multicomponent phosphate melts was found. The obtained compounds were investigated using IR spectroscopy, X-ray powder diffraction and optical microscopy.

\section{Experimental}

Peculiarities of the phase formation in the self-flux of systems $\mathrm{M}_{2}^{\prime} \mathrm{O}-\mathrm{P}_{2} \mathrm{O}_{5}-\mathrm{TiO}_{2}-M^{\prime} \mathrm{O}$ $\left(M^{\prime}-\mathrm{Rb}, \mathrm{Rb} / \mathrm{K}, M^{\prime \prime}-\mathrm{Cu}, \mathrm{Zn}\right)$ were investigated at different molar ratios $M^{l} / \mathrm{P}=$ $0.5-1.3$ and fixed values $\mathrm{Ti} / \mathrm{P}=0.3, \mathrm{Ti} / M^{\prime \prime}=$ 1.0 in temperature range of $1000-650^{\circ} \mathrm{C}$. Hte influence of the nature of alkaline metals on interaction in multicomponent potassium-rubidium containing systems was determined at different values $\mathrm{Rb} / \mathrm{K}=0.5,1.0$ or 2.0 and fixed $\mathrm{Ti} / \mathrm{P}=0.3, \mathrm{Ti} / M^{\prime \prime}=1.0$. All initial components $\mathrm{KPO}_{3}, \mathrm{RbH}_{2} \mathrm{PO}_{4}$, $\mathrm{Rb}_{2} \mathrm{CO}_{3}, \mathrm{CuO}, \mathrm{ZnO}, \mathrm{TiO}_{2}$ and $\mathrm{H}_{3} \mathrm{PO}_{4}$ materials were of analytical grade.

The experimental procedure included the obtaining of homogeneous self-flux at $1000^{\circ} \mathrm{C}$ and their further gradual cooling to $800-500^{\circ} \mathrm{C}$ for crystallization of the complex phosphates. The final temperature depended on the initial ratio $M^{l} / \mathrm{P}$ in the melt. The completeness of the dissolving of oxides and beginning of the crystal formation were controlled by observing the melts and periodically sampling. The rapid quenching small droplets of equilibrium liquid phase were dissolved in water and in further insoluble residue were examined by optical microscopy. At the final temperature of crystallization the crystalline phases were washed up by water.

The phase compositions of the obtained samples were determined by X-ray diffraction (XRD). Diffractometer Shimadzu XRD-
6000 with $\mathrm{Cu} \mathrm{K} \alpha$ radiation $(\lambda=1.5418 \AA)$ was used. Data were collected over the $2 \theta$ range $5-90^{\circ}$, with the step $0.02^{\circ}$ and $1 s$ of exposure per step. Fourier-transformed infrared (FTIR) spectra were obtained using Nicolet Nexus FTIR spectrometer (in the range of 4000 and $400 \mathrm{~cm}^{-1}$ wave numbers) for the samples pressed into the pellets of $\mathrm{KBr}$. Elemental analysis of the prepared phosphates was determined employing XRF method using Elvax standard less light spectrometer equipped with ED detector.

\section{Results and discussion}

At the first step the influence of the nature of the alkali metals on dissolution of the mixture $\mathrm{TiO}_{2}+M^{\prime \prime} \mathrm{O}$ in phosphate melts was investigated. It was found that the rate of dissolution of the oxides mixture in rubidium phosphate self-flux considerably depends on the ratio $\mathrm{Rb} / \mathrm{P}$ in the initial melt. Thus, at $\mathrm{Rb} / \mathrm{P}<1.0$ homogenization of the melts was reached after $2 \mathrm{~h}$ at the temperature of $1000^{\circ} \mathrm{C}$. At the same time the complete dissolution of the oxides occurs simultaneously with melting the rubidium phosphate for ratios $R b / P \geq 1.0$. It should be noted, that adding the small amounts of potassium to the initial melts leads to decreasing of solubility capability of the melts. Thus, in self-flux with $\mathrm{Rb} / \mathrm{K}=2.0$ and $(\mathrm{Rb}+\mathrm{K}) / \mathrm{P}=1.0$ the dissolving of the oxides needs heating at $1000^{\circ} \mathrm{C}$ during $1 \mathrm{~h}$. At $\mathrm{Rb} / \mathrm{K}=0.5$ the time of homogenization of the melts is increased to $2 \mathrm{~h}$. Thus, this result indicates about decreasing of the dissolving capability of rubidiumcontaining phosphate melts relative to the mixture of oxides $\mathrm{TiO}_{2}+M^{\prime l} \mathrm{O}$, in the case of potassium presence.

The results of the phase analysis for synthesized phosphates showed that composition of the obtained phosphates depends on the molar ratio $M^{l} / \mathrm{P}$ in the initial melts and the nature of the alkali metals (Table). Thus, for the rubidiumcontaining phosphate melts in the $\mathrm{P}_{2} \mathrm{O}_{5}$-rich region $(\mathrm{Rb} / \mathrm{P}<1.0)$ only double rubidium and titanium phosphate $\mathrm{RbTi}_{2}\left(\mathrm{PO}_{4}\right)_{3}$ was obtained. The latter compound belongs to rhombohedral crystal system (sp.gr. R3c) and calculated lattice parameters: $a=8.239(2)$ and $c=23.563(3) \AA$ are close to the corresponding data from JSPDS (\#00-082-2264) and the literature [10]. It was found that at $\mathrm{Rb} / \mathrm{P}=0.5$, a considerable amount of amorphous component and the initial titanium oxide are as impurities (Table, Fig. 1). The halo in the 
Table. Phase composition of obtained phosphates in the systems $\mathrm{Rb}_{2} \mathrm{O}-\mathrm{P}_{2} \mathrm{O}_{5}-\mathrm{TiO}_{2}-\mathrm{M}^{\prime \prime} \mathrm{O}$ and $(\mathrm{Rb} / \mathrm{K})_{2} \mathrm{O}-\mathrm{P}_{2} \mathrm{O}_{5}-\mathrm{TiO}_{2}-M^{\prime \prime} \mathrm{O}\left(M^{\prime \prime}-\mathrm{Cu}, \mathrm{Zn}\right) \mathrm{Ti} / \mathrm{P}_{(m o l)}=0.30, \mathrm{Ti} / M^{\prime \prime}=1.0$ and $(\mathrm{Rb}+\mathrm{K}) / \mathrm{P}=1.0$, $\Delta T=1000-650^{\circ} \mathrm{C}$

\begin{tabular}{|c|c|c|c|}
\hline \multicolumn{2}{|r|}{$\mathrm{Rb}_{2} \mathrm{O}-\mathrm{P}_{2} \mathrm{O}_{5}-\mathrm{TiO}_{2}-\mathrm{M}^{\prime \prime} \mathrm{O}$} & \multicolumn{2}{|r|}{$(\mathrm{Rb} / \mathrm{K})_{2} \mathrm{O}-\mathrm{P}_{2} \mathrm{O}_{5}-\mathrm{TiO}_{2}-\mathrm{M}^{\prime \prime} \mathrm{O}(\mathrm{Rb}+\mathrm{K}) / \mathrm{P}=1.0$} \\
\hline $\mathrm{Rb} / \mathrm{P}_{(\text {mol. })}$ & Phase composition & $\mathrm{Rb} / \mathrm{K}_{(m o l .)}$ & Phase composition \\
\hline 0.50 & $\begin{array}{c}\mathrm{RbTi}_{2}\left(\mathrm{PO}_{4}\right)_{3}: M^{\prime \prime}+\mathrm{TiO}_{2}+\text { amorphic } \\
\text { component }\end{array}$ & 0.5 & $(\mathrm{Rb} / \mathrm{K}) \mathrm{Ti}_{2}\left(\mathrm{PO}_{4}\right)_{3}: M^{\prime \prime}<(\mathrm{Rb} / \mathrm{K})_{1+2 x} \mathrm{Ti}_{2-x} M_{x}^{\prime \prime}\left(\mathrm{PO}_{4}\right)_{3}$ \\
\hline 0.85 & $\mathrm{RbTi}_{2}\left(\mathrm{PO}_{4}\right)_{3}: \mathrm{M}^{\prime \prime}+\mathrm{TiO}_{2}$ & & \\
\hline 1.0 & $\mathrm{Rb}_{3} \mathrm{Ti}_{3} \mathrm{O}\left(\mathrm{P}_{2} \mathrm{O}_{7}\right)\left(\mathrm{PO}_{4}\right)_{3}: \mathrm{M}^{\prime \prime}$ & 1.0 & Glass \\
\hline 1.2 & $\mathrm{Rb}_{3} \mathrm{Ti}_{3} \mathrm{O}\left(\mathrm{P}_{2} \mathrm{O}_{7}\right)\left(\mathrm{PO}_{4}\right)_{3}: \mathrm{CuRbZnPO}$ & 2.0 & $(\mathrm{Rb} / \mathrm{K}) \mathrm{Ti}_{2}\left(\mathrm{PO}_{4}\right)_{3}: \mathrm{M}^{\prime \prime}>(\mathrm{Rb} / \mathrm{K})_{1+2 x} \mathrm{Ti}_{2-x} \mathrm{M}_{x}^{\prime \prime}\left(\mathrm{PO}_{4}\right)_{3}$ \\
\hline 1.3 & Glass & & \\
\hline
\end{tabular}

region $2 \theta=20-35^{\circ}$ on the diffraction pattern of the obtained sample $(R b / P=0.5)$ confirms the presence of amorphous component in its composition (Fig. 1). The nature of this amorphous component is caused by the presence of over cooled pieces of phosphate glass insoluble in water, which can be observed using an optical microscope.

Increase of the molar ratio $\mathrm{Rb} / \mathrm{P}$ to 0.85 in the initial melt almost no influence on the composition of the crystal phase, but significantly reduces the amount of starting $\mathrm{TiO}_{2}$ in the obtained samples and disappearance of the amorphous component (see Table).

Formation of the crystals of the plate form and colorless for $\mathrm{Zn}$ or light blue for $\mathrm{Cu}$ was recorded during cooling self-flux with $\mathrm{Rb} / \mathrm{P}=1.0$ up to $830^{\circ} \mathrm{C}$ (Fig. 2). Formation of the mixed anionic phosphates $\mathrm{Rb}_{3} \mathrm{Ti}_{3} \mathrm{O}\left(\mathrm{P}_{2} \mathrm{O}_{7}\right)\left(\mathrm{PO}_{4}\right)_{3}$ doped by $\mathrm{Cu}(<1$ at. \%) or $\mathrm{Zn}(<5$ at. $\%)$ were established using powder X-ray diffraction data (Fig. 1) and energy-dispersive X-ray fluorescence method at analysis of the individual crystals. The results of the crystal structure studies of phosphate $\mathrm{Rb}_{3} \mathrm{Ti}_{3} \mathrm{O}\left(\mathrm{P}_{2} \mathrm{O}_{7}\right)(\mathrm{PO} 4)_{3}$ were early shown in [11]. Its three-dimensional framework built up from isolated $\mathrm{TiO}_{6}$-polyhedra, $\left[\mathrm{Ti}_{2} \mathrm{O}_{11}\right]$-dimers, phosphate and pyrophosphate groups. Rubidium cations are located in the channels of the framework and are surrounded by eight oxygen atoms.

The presence of $\mathrm{P}_{2} \mathrm{O}_{7}$-group in obtained $\mathrm{Rb}_{3} \mathrm{Ti}_{3} \mathrm{O}\left(\mathrm{PO}_{4}\right)_{3}\left(\mathrm{P}_{2} \mathrm{O}_{7}\right)$ was confirmed using IR spectroscopy method (Fig. 3). The bands in the frequency region $800-650 \mathrm{~cm}^{-1}$ correspond to symmetric vibrations of the P-O-P $\left(v_{s}\right)$. The complex view of spectrum in the region of $1220-900 \mathrm{~cm}^{-1}$ is due to the overlap of symmetric $\left(v_{s}\right)$ and asymmetric $\left(v_{a s}\right)$ vibrations of $\mathrm{PO}_{3}$ and $\mathrm{PO}_{4}$-tetrahedra in $\mathrm{P}_{2} \mathrm{O}_{7}$-group.
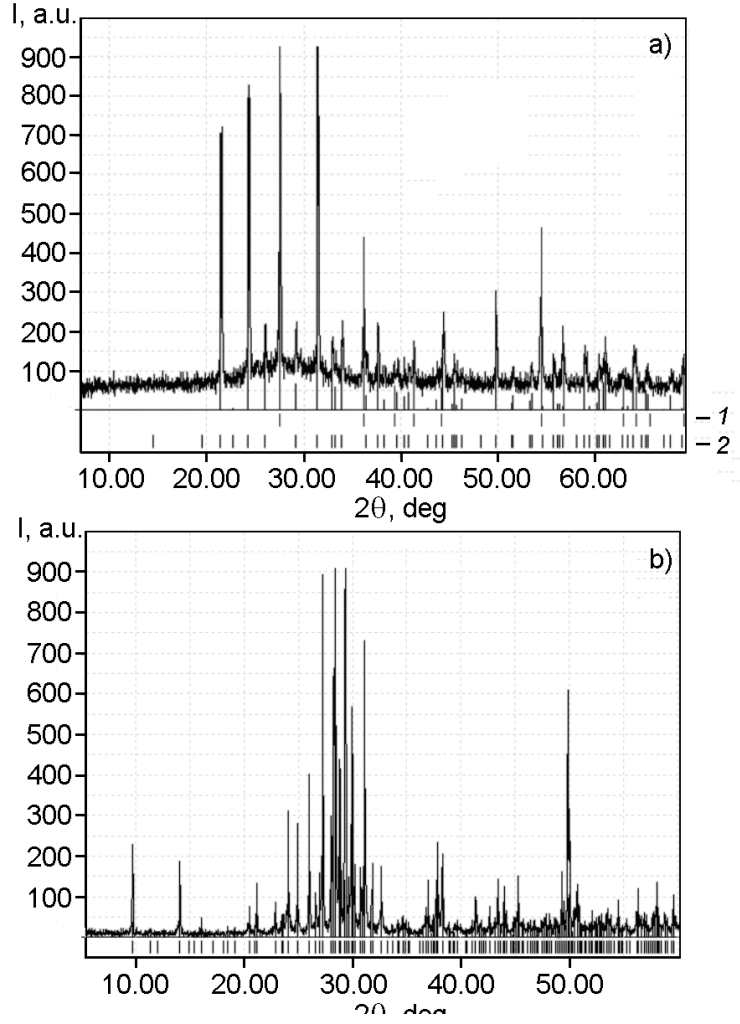

Fig. 1. XRD patterns for prepared crystalline phases: (a) $\mathrm{RbTi}_{2}\left(\mathrm{PO}_{4}\right)_{3}: \mathrm{Zn}$ (stroke 2), $\mathrm{TiO}_{2}$ (stroke 1) and (b) $\mathrm{Rb}_{3} \mathrm{Ti}_{3} \mathrm{O}\left(\mathrm{P}_{2} \mathrm{O}_{7}\right)\left(\mathrm{PO}_{4}\right)_{3}: \mathrm{Cu}$.

The main peculiarity of multicomponent melts with molar ratios $\mathrm{Rb} / \mathrm{P}>1.0$ is its high dissolving capability to the both mixture of polyvalent metal oxides and complex phosphates that are formed in this region. This fact explains the relatively low temperatures of the crystal formation about $650-500^{\circ} \mathrm{C}$ in such melts. Thus, the start of crystallization in the melts with value $\mathrm{Rb} / \mathrm{P}=1.2$ is observed below $650^{\circ} \mathrm{C}$.

In the Cu-containing melt with $\mathrm{Rb} / \mathrm{P}=$ 1.2 , as that at $R b / P=1.0$, the light blue crystals of mixed anionic phosphate $\mathrm{Rb}_{3} \mathrm{Ti}_{3} \mathrm{O}\left(\mathrm{P}_{2} \mathrm{O}_{7}\right)(\mathrm{PO} 4)_{3}$ doped by $\mathrm{Cu}$ were ob- 

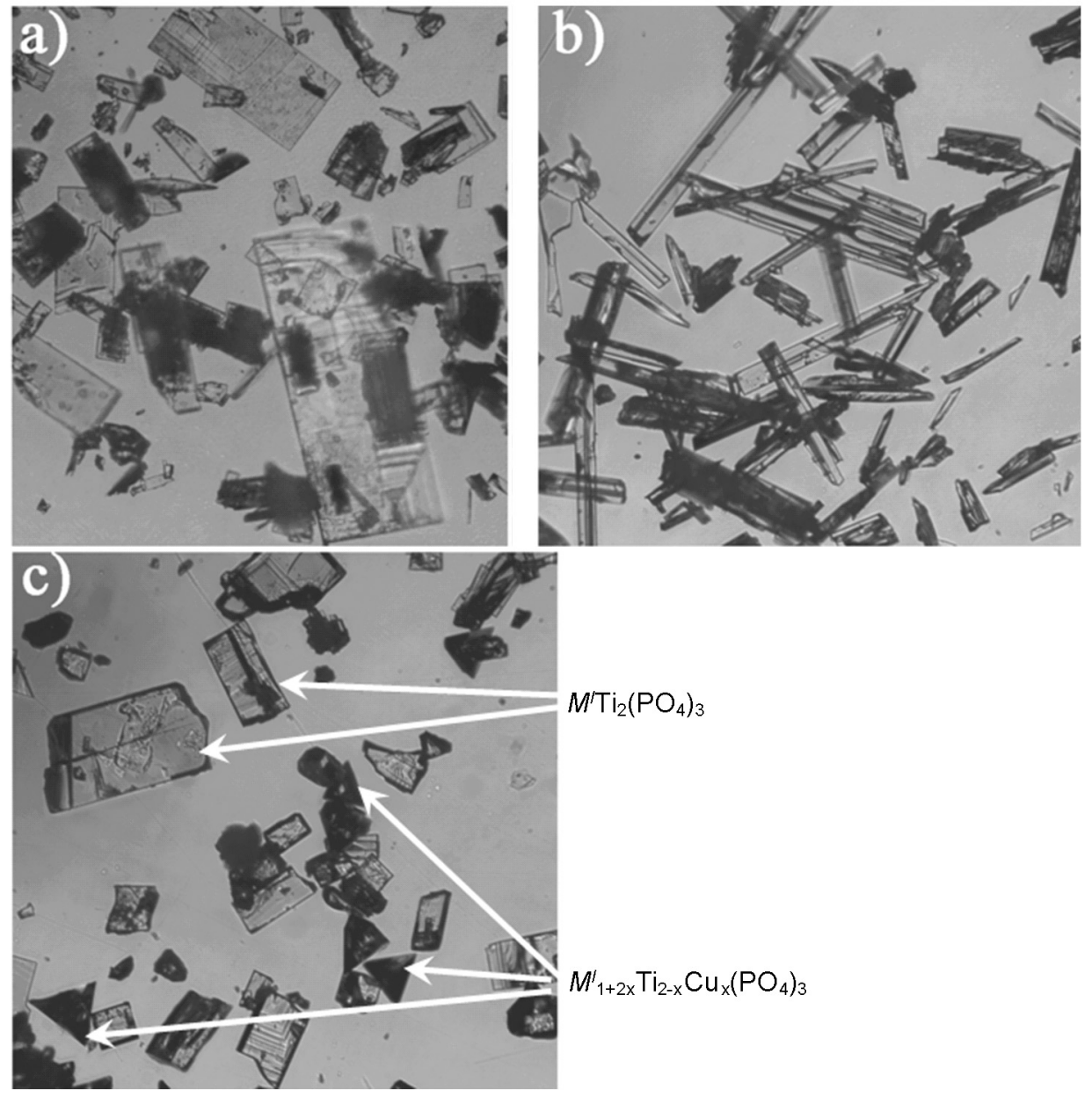

Fig. 2. Microphotographies of single crystals of prepared phosphates: $\mathrm{Rb}_{3} \mathrm{Ti}_{3} \mathrm{O}\left(\mathrm{P}_{2} \mathrm{O}_{7}\right)\left(\mathrm{PO}_{4}\right)_{3}: \mathrm{Cu}$ (a), $\mathrm{RbZnPO}_{4}$ (b) and mixture of $\mathrm{M}^{\prime} \mathrm{Ti}_{2}\left(\mathrm{PO}_{4}\right)_{3}+M_{1+2 x}^{\prime} \mathrm{Ti}_{2-x} \mathrm{Cu}_{x}\left(\mathrm{PO}_{4}\right)_{3}$ (c).

tained. In the case of $\mathrm{Zn}$-containing melt the colorless rods-like crystals below $630^{\circ} \mathrm{C}$ were observed (Fig. 2). According to powder $\mathrm{X}$-ray diffraction the formation of orthorhombic double rubidium and zinc phosphate $\mathrm{RbZnPO}_{4}$ was established. Its calculated lattice parameters $(a=8.960(6), b=8.856$ (6), $c=5.408$ (7) $\AA$ ) are close to the corresponding data from JSPDS (\#00-022-1271). The IR spectrum of the synthesized $\mathrm{RbZnPO}_{4}$ is shown in Fig. 3. The bands in the frequency region of $1150-900 \mathrm{~cm}^{-1}$ (symmetric $v_{s}$ and asymmetric $v_{a s}$ vibration of $\mathrm{PO}_{4}$ tetrahedron) and $650-520 \mathrm{~cm}^{-1}$ (deformation vibrations of the $\mathrm{P}-\mathrm{O}$ ) confirm the presence in its structure of isolated $\mathrm{PO}_{4}$ tetrahedra.

Further increasing of the ratio $\mathrm{Rb} / \mathrm{P}$ to 1.3 in the initial melts leads to their solidification under $550^{\circ} \mathrm{C}$ (Table 1).

Investigation of crystallization in the systems $(\mathrm{Rb} / \mathrm{K})_{2} \mathrm{O}-\mathrm{P}_{2} \mathrm{O}_{5}-\mathrm{TiO}_{2}-M^{\prime \prime} \mathrm{O} \quad\left(M^{\prime \prime}-\right.$
$\mathrm{Cu}, \mathrm{Zn})$ showed that the phase composition of products depends on molar ratio $\mathrm{Rb} / \mathrm{K}$ in the initial melts (Table). Thus, cooling of the self-flux with $\mathrm{Rb} / \mathrm{K}=2.0$ to temperature $850^{\circ} \mathrm{C}$ caused to formation of the platelike crystals, which have blue color in the case of $\mathrm{Cu}$. Formation of similar crystals was found in the rubidium-containing melts with molar ratio $\mathrm{Rb} / \mathrm{P}<1$. Further cooling of the melts to $750^{\circ} \mathrm{C}$ leads to increase of these crystals size and to formation of the new crystals of tetrahedral form. According to phase analysis of the mixture of phosphates: $M^{\prime} \mathrm{Ti}_{2}\left(\mathrm{PO}_{4}\right)_{3}$ (rhombohedral system, sp.gr. R3c) and $M^{\prime}{ }_{1+2 x} \mathrm{Ti}_{2-\mathrm{x}} \mathrm{M}^{\prime \prime}{ }_{x}\left(\mathrm{PO}_{4}\right)_{3}$ langbeinite-related (cubic system, sp.gr. P2 3 ) were obtained. This result indicates that the presence of potassium in multicomponent rubidium- containing melts caused the shift of region of the phosphate formation $M^{\prime} \mathrm{Ti}_{2}\left(\mathrm{PO}_{4}\right)_{3}$ from acidic $(\mathrm{Rb} / \mathrm{P}<1)$ to metaphosphate $((R b+K) / P=1.0)$. This result indicates about influence of alkaline metals 


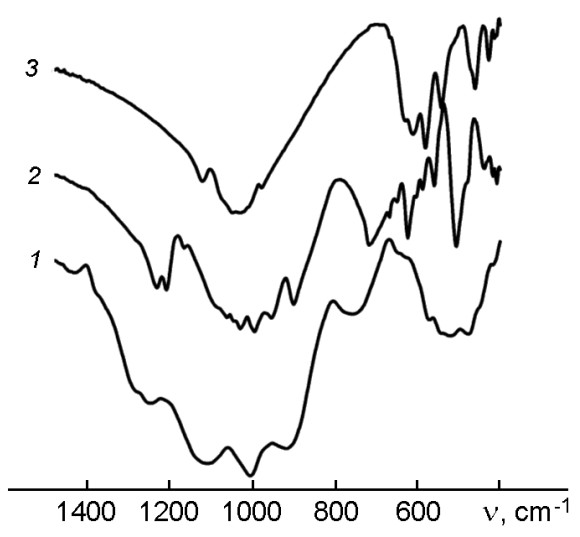

Fig. 3. FTIR-spectra of obtained phosphates: $\mathrm{RbTi}_{2}\left(\mathrm{PO}_{4}\right)_{3}: \mathrm{Zn}$ (curve 1), $\mathrm{Rb}_{3} \mathrm{Ti}_{3} \mathrm{O}\left(\mathrm{P}_{2} \mathrm{O}_{7}\right)\left(\mathrm{PO}_{4}\right)_{3}: \mathrm{Cu}$ (curve 2) and $\mathrm{RbZnPO}_{4}$ (curve 3 ).

nature on interaction in the phosphate melts. In the case of equal quantity of potassium and rubidium in the melts $(\mathrm{Rb} / \mathrm{K}=$ 1.0) the solidification of the self-fluxes without crystal formation were observed below $650^{\circ} \mathrm{C}$. Further increasing of potassium content in the melts to value $\mathrm{Rb} / \mathrm{K}=$ 0.5 caused the formation of the mixture of crystalline phases $M^{\prime} \mathrm{Ti}_{2}\left(\mathrm{PO}_{4}\right)_{3}$ (sp.gr. R3c) and $M_{1+2 x}^{\prime} \mathrm{Ti}_{2-x} M^{\prime \prime}{ }_{x}\left(\mathrm{PO}_{4}\right)_{3}$ (sp.gr. P2 3 ).

The results of investigation of phase formation in the self-flux systems $\mathrm{K}_{2} \mathrm{O}-\mathrm{P}_{2} \mathrm{O}_{5}$ $\mathrm{TiO}_{2}-M^{\prime l} \mathrm{O}\left(M^{\prime l}-\mathrm{Cu}, \mathrm{Zn}\right)$ are presented in $[12,13]$. The conditions of formation of NASICON-related phosphates $\mathrm{KTi}_{2}\left(\mathrm{PO}_{4}\right)_{3}$, $\mathrm{K}_{1+y} \mathrm{Ti}_{2-x} M^{\prime \prime}{ }_{x}\left(\mathrm{PO}_{4}\right)_{3}$, langbeinite $\mathrm{K}_{2} \mathrm{Ti}_{1.5} M^{\prime \prime}{ }_{0.5}\left(\mathrm{PO}_{4}\right)_{3}$ and $\mathrm{KTiOPO}_{4}$ have been established [12, 13]. The fields of formation of different type of potassium or rubidium-containing phosphate are closed. However, formation of the langbeinite-type phosphate for potassium and mixed anionic phosphate doped by $\mathrm{Cu}$ or $\mathrm{Zn}$ for rubidium is the main difference between investigated and published systems $[12,13]$. Obtained results indicate that the presence of potassium in the self-flux caused formation of the langbeinite-related phosphates (for investigated molar ratios $\left.\mathrm{Ti} / \mathrm{P}=0.3, \mathrm{Ti} / M^{\prime l}=1.0\right)$. The formation of the langbeinite-related complex phosphate in potassium-rubidiumcontaining self-flux additionally confirms this conclusion.

\section{Conclusions}

The results of investigation of peculiarities of phase formation in the self-flux systems $M_{2}^{\prime} \mathrm{O}-\mathrm{P}_{2} \mathrm{O}_{5}-\mathrm{TiO}_{2}-M^{\prime \prime} \mathrm{O}\left(M^{\prime}-\mathrm{Rb}, \mathrm{Rb} / \mathrm{K}\right.$, $\left.M^{\prime \prime}-\mathrm{Cu}, \mathrm{Zn}\right)$ (the temperature range $1000-$ $650^{\circ} \mathrm{C}$ and molar ratios $M^{\prime} / \mathrm{P}=0.5-1.3$, $\left.\mathrm{Ti} / \mathrm{P}=0.3, \mathrm{Ti} / M^{\prime \prime}=1.0\right)$ showed the influence of alkaline metals nature on composition of obtained complex phosphates. In the case of rubidium-containing self-flux the formation of NASICON-type phosphate and mixed anionic phosphate $\mathrm{Rb}_{3} \mathrm{Ti}_{3} \mathrm{O}\left(\mathrm{PO}_{4}\right)_{3}\left(\mathrm{P}_{2} \mathrm{O}_{7}\right)$ doped by $\mathrm{Cu}$ or $\mathrm{Zn}$ were established. The langbeinite-related phosphate was prepared in the mixed potassium-rubidium containing systems that indicates about prevail influence of potassium on interaction in multicomponents phosphate melts. The obtained results can be used to create of the new functional materials on the basis of composites that contain phosphates with different structure and properties.

\section{References}

1. P.F.Henry, E.M.Hughes, M.T.Weller, J.Chem. Soc., Dalton Trans., 555 (2000).

2. M.Roth, N.Angert, M.Tseitlin et al., Opt. Mater., 16, 131 (2001).

3. J.Wang, J.Wei, Y.Liu et al., Prog.Cryst. Growth and Charact., 40, 3 (2000).

4. R.Essehli, B.El Bali, S.Benmokhtar et al., J. Alloys Compd., 509, 1163 (2011).

5. J.K.Feng, L.Lu, M.O.Lai, J.Alloys Compd., 501, 255 (2010).

6. J.-K.Sun, F.-Q.Huang, Y.-M.Wang, J.Alloys Compd., 469, 327 (2009).

7. A.El.Bouari, A.El.Jazouli, S.Benmokhtar et al., J.Alloys Compd., 503, 480 (2010).

8. I.V.Ogorodnyk, V.N.Baumer, I.V.Zatovsky et al., Acta Crystallogr., B63, 819 (2007).

9. S.P.Kumar, B.Gopal, J.Alloys Compd., 615, 419 (2014).

10. R.Duhlev, Acta Cryst., C50, 1525 (1994).

11. T.A.Harrison, T.E.Gier, J.C.Calabrese et al., J. Solid State Chem., 111, 257 (1994).

12. I.V.Ogorodnyk, I.V.Zatovsky, N.S.Slobodyanyk, Reports of NAS of Ukraine, 1, 148 (2007).

13. I.V.Ogorodnyk, I.V.Zatovsky, N.S.Slobodyanyk, Herald of the T. Shevchenko National University of Kyiv, 43, 14 (2006). 